Conny Helder is het nieuwe gezicht van ActiZ. Ze vliegt van overleg naar overleg en knokt bij landelijke partijen om aandacht voor de ouderenzorg.

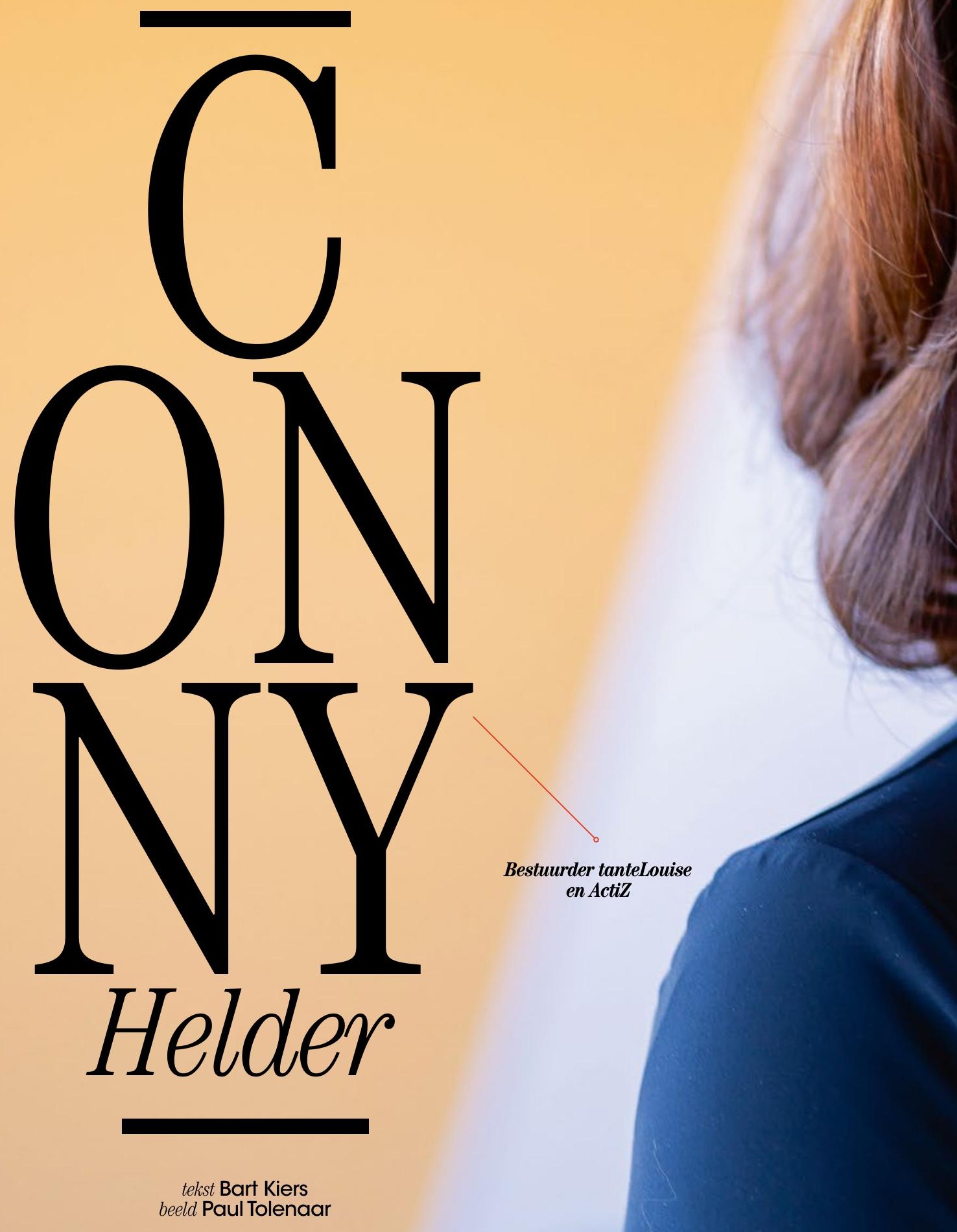




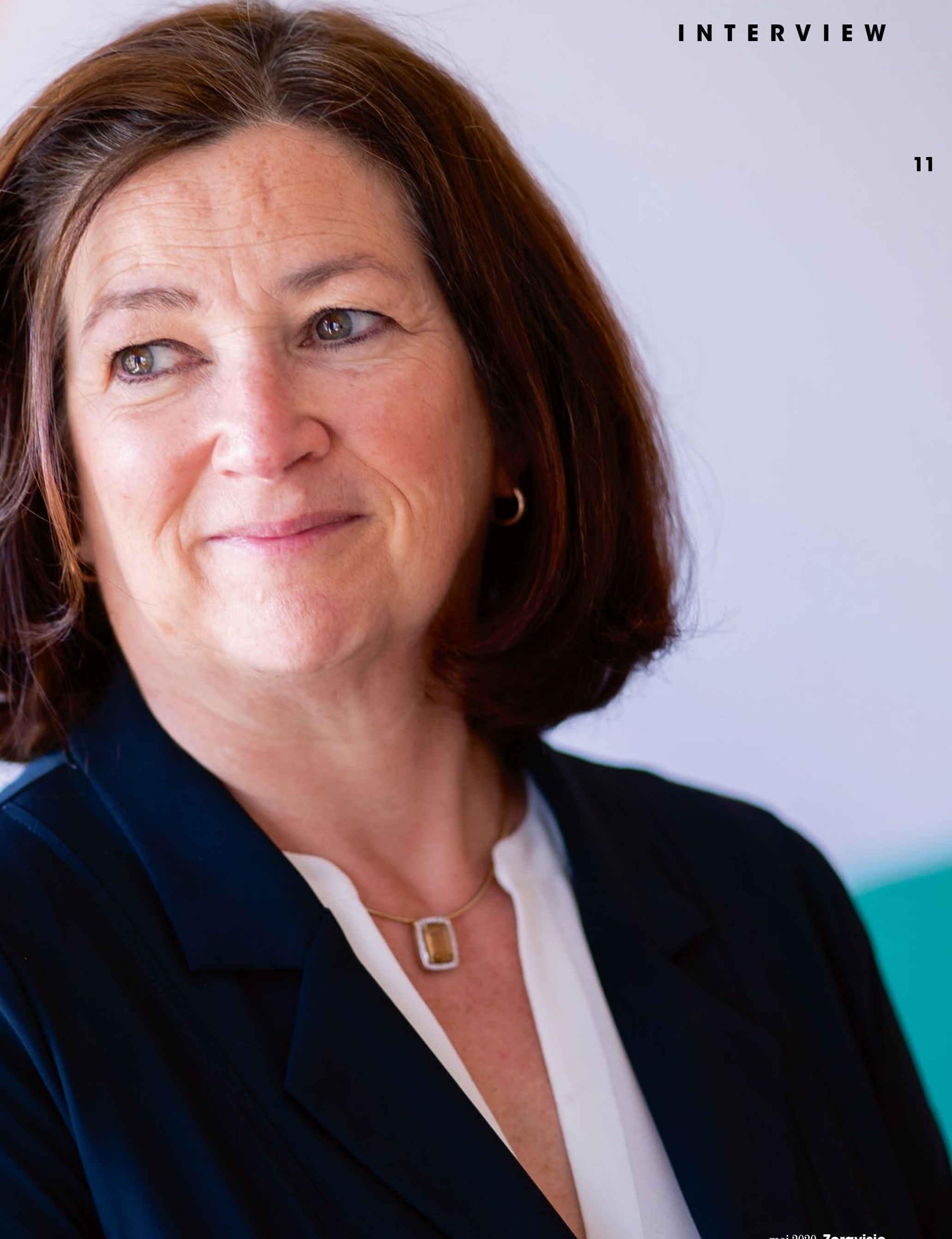




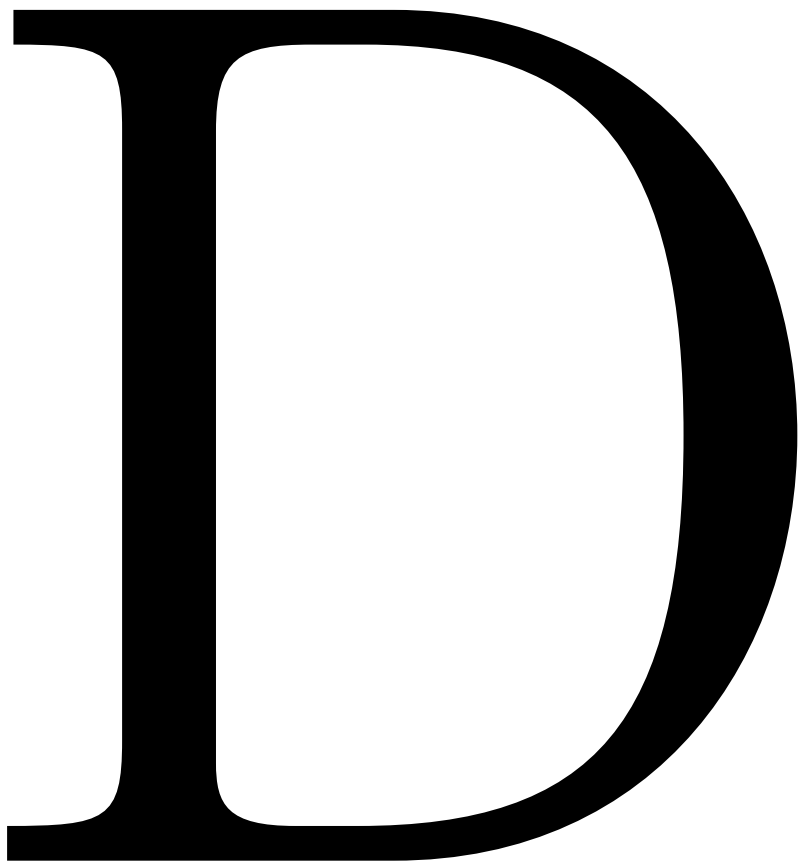

De coronacrisis begint voor Conny Helder als een sprint. Het startschot is het RIVM-persbericht op vrijdagavond 13 maart: iedereen moet thuis werken, behalve de zorgverleners in de ziekenhuizen. Het RIVM is de ouderenzorg vergeten. Dat zou vaker gebeuren tijdens de coronacrisis. 'Als iedereen met een kuchje of een snotneus thuis moet blijven, is ook in de verpleging, verzorging en thuiszorg (vvt) de continuïteit van zorg weg. Dat kan niet. Na overleg met het RIVM begrepen ze dat onze zorgverleners gelijkgesteld moesten worden aan medewerkers in ziekenhuizen. Het duurde nog wel even tot dit op hun website was hersteld', vertelt Helder in een interview op 23 april.

$\mathrm{Na}$ het RIVM-persbericht ontstaat er intensieve dynamiek tussen vvt-bestuurders in Brabant. 'Ik zat op de rand van mijn bed, omdat mijn telefoon daar aan de lader lag. Er werd direct een app-groepje opgericht van Brabantse vvt-bestuurders. Ik was continu aan het bellen en appen. Er was contact met het ministerie over wat er op ons afkwam en hoe we het zouden gaan doen. Pas 4,5 uur later kwam ik van de rand van het bed af. Die dynamiek is niet meer gestopt en gaat ook in de weekenden door.' De sprint gaat over in een marathon.

\section{Paniek in Brabant}

In Noord-Brabant, de landingsplaats voor het coronavirus in Nederland, is in maart paniek. Verpleeghuizen in de brandhaarden Uden en Oss zien dat de besmetting zich als een veenbrand verspreidt. Ze willen een bezoekverbod om de verspreiding in te dammen. Bij tanteLouise zijn er weinig besmettingen. West-Brabant is een witte vlek in coronaland. Door de heftige verhalen van haar collega-bestuurders, beseft Helder dat een preventieve sluiting onvermijdelijk is. 'Dat de rest van Nederland in het begin van de coronacrisis niet was aangehaakt, voelde vreemd. Als je niet in de brandhaard zit, weet je niet tegen welke vijand je strijdt. Dat was bij tijd en wijle lastig. Je voelt je alleen staan. Ook binnen het bestuur van ActiZ, want de helft zat nog in de andere wereld. Dat is ook logisch, maar gelukkig hebben we het snel opgelost.' Waar de meeste mensen door de coronacrisis veel thuis zijn, vliegt Conny Helder juist van overleg naar overleg. Ze draagt drie bestuurlijke petten: van branchevereniging ActiZ, van zorgorganisatie tanteLouise en van het regionale overleg in Noord-Brabant. Haar man, huisarts, is ook enorm druk. 'Mijn dochter van 21 jaar, die net het ouderlijk huis had verlaten, wacht thuis met de warme pot tot papa en mama thuis komen. Daar loopt nog een zoon van 18 jaar doorheen.'

Vrijwel dagelijks schuift Helder aan bij het RONAZ. Dat is het regionale informele overlegpodium voor de niet-acute zorg. Het jonge broertje van het Regionaal Overleg Acute Zorg (ROAZ) is geboren in de eerste fase van de coronacrisis, omdat er voor de langdurige zorg geen formeel regionaal orgaan bestaat. Helder vertegenwoordigt West-Brabant in het RONAZ-bestuur. Binnen het RONAZ helpen de bestuurders elkaar onder meer met het verkrijgen van beschermingsmiddelen, omdat de voorraden beperkt blijken te zijn.

\section{Vliegende start}

Helder is per 1 januari op landelijk niveau actief als algemeen bestuurslid van ActiZ. Van haar voornemen een rondje langs de velden te maken, om in den lande bestuurders te leren kennen, komt door de coronacrisis niets terecht. Zonder de geplande mediatraining stort ze zich op haar nieuwe rol als ActiZ-woordvoerder. 'Het was training on the job. Ik had welgeteld twee vergaderingen gehad en voor het eerst mijn ActiZ-pasje gebruikt toen we de crisis in werden geschoten. Als je druk bent, heb je geen tijd om na te denken. Het helpt als je met je voeten in de klei staat. In Noord-Brabant hadden we snel in de gaten door welke molen we zouden gaan. Ik ken alle dossiers van binnenuit door de vele contacten in Brabant. Ik praat veel, denk mee en voel mee. Anders had ik die rol minder goed kunnen spelen.'

Helder schakelt doorlopend op alle bestuurlijke niveaus. Elke dag, ook in het weekend. Het werk 


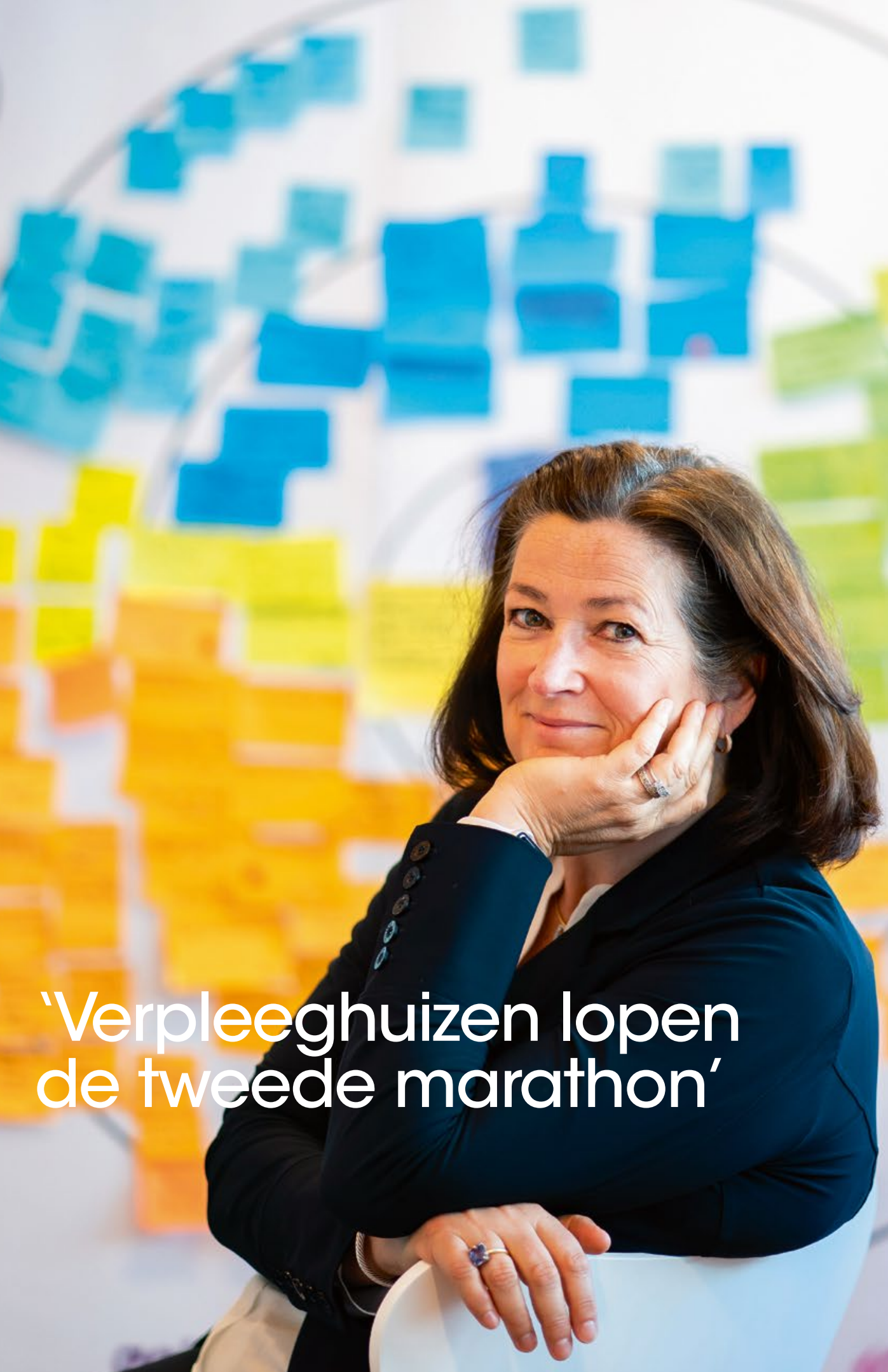


laat amper ruimte voor privé. 'We hebben bij tanteLouise ons eigen crisisteam. Dagelijks heb ik een call met alle landelijke partijen. Daarnaast ben ik een soort olievrouwtje. Op het ene moment regel ik beschermende schorten voor collega's die ziekenhuizen ontlasten met cohort-afdelingen, het andere moment praten we over een heropstart van ziekenhuizen. Het is prettig dat er weinig onmin is tussen zorgbestuurders. Er is geen tijd voor politiek gedoe onder elkaar. Als je haast hebt, zijn discussies kort. Iedereen heeft een pragmatische instelling en steekt de handen uit de mouwen.'

\section{WAT WAS HET MOEILIJKSTE MOMENT IN DE CRISIS? 'De} preventieve sluiting van verpleeghuizen was een zware verantwoordelijkheid. Die voelde als een molensteen. Kinderen die niet naar hun ouders kunnen, partners die vijftig jaar getrouwd zijn en elkaar niet mogen zien. Je realiseert je dat je als medebesluitvormer invloed hebt op de uitkomst.'

ACTIZ WAS AANVANKELIJK TEGEN. 'Nou, wij stonden niet te trappelen. Maar in Noord-Brabant waren wij al wel om. We zagen hoe het virus zich vanuit de brandhaarden Oss, Uden en Veghel in een weekend verspreidde van het ene naar het andere verpleeghuis. Dus de gebieden daaromheen wilden die bezoekregeling. In West-Brabant hadden we nog geen besmetting, maar toch moesten we solidair zijn vanwege het bezoekverbod. Omdat ik kon waarnemen hoe snel het virus zich verspreidde, stond ik er inhoudelijk ook achter. Toen Verenso de preventieve sluiting voor heel Nederland wilde, schakelden wij makkelijker mee. Er was een leidende coalitie van bestuurders die anderen aansprak op hun solidariteit. Je doet het omdat het

\section{'Het is onvermijde- lijk dat controle- mechanismen deels terugkomen'}

\section{CONNY HELDER}

(1958) begon haar loopbaan als operatieZe belandde al snel in het management. Eerst bij ziekenhuizen in Den Haag, Amsterdam en later als assistent in Den Haag. divisiemanager in het UMC Utrecht. In 2010 werd ze bestuursvoorzitter van SGE (Stichting Gezondheidscentra Eindhoven). In 2017 gaat ze aan de slag als bestuursvoorzitter van tantelouise, vvt-aanbieder in Louise heeft zeventien locaties, een omzet van circa 100 miljoen euro en er werken 1.900 medewerkers West-Brabant. Tante-

nodig is, maar je realiseert je ook wat de gevolgen van je handelen is.'

EEN DUIVELS DILEMMA. 'Mensen die niet in de brandhaard zitten, benaderen het als een normale besluitvorming. Maar het was niet een kwestie van voors en tegens tegen elkaar afwegen en alles afpellen. Zo'n beslissing moet je nemen, terwijl je nog veel niet weet van het virus. We weten nu dat het heel besmettelijk is, dat mensen er heel ziek van worden, dat kwetsbare mensen vaker overlijden. We namen die beslissing omdat we dachten dat dat het beste is. De geschiedenis zal leren of het doel de middelen heiligt.'

HOE LANG IS HET BEZOEKVERBOD HOUDBAAR? 'Dat is de verkeerde vraag. Je moet kijken of het zinvol is in de bestrijding van de infectieziekte. In het weekend dat het aantal besmettingen erg opliep, was "bij oma op bezoek" nog het enige uitje. Verpleeghuizen waren een soort broedplaats voor de infectie. Er waren veel mensen in kleine ruimtes, die ook nog aan elkaar zaten. Ze besmetten elkaar en namen het virus mee de samenleving in. Dat wilden we stoppen. Dat moesten we snel beslissen. Voor het versoepelen van de bezoekregeling komt diezelfde belangenafweging weer op tafel. Dan nemen mensen het virus mee de samenleving in en krijg je een tweede piek. Dat moet je dus heel voorzichtig en geleidelijk doen.'

ZIEKENHUIZEN KREGEN IN HET BEGIN ALLE BESCHERMINGSMIDDELEN. IS ER TIJD VERLOREN GEGAAN BIJ HET INDAMMEN VAN DE CRISIS? 'Er is kostbare tijd verloren gegaan om rust te brengen in de vvt. Terwijl we echt gestreden hebben voor meer testen en een andere verdeelsleutel voor beschermingsmiddelen. We hebben in de eerste fase ook steeds aangegeven dat we veel coronapatiënten kunnen opvangen als ziekenhuizen overlopen. Onze geriatrische herstelafdelingen zijn ziekenhuiswaardig, ook qua personeelsbezetting. Maar dat werd niet gehoord. Er werden patiënten naar andere regio's overgeplaatst, terwijl wij in de vvt nog ruimte hadden. Die komen nu terug en hebben herstelzorg nodig. Binnen verpleeghuizen gaat de veenbrand door. 


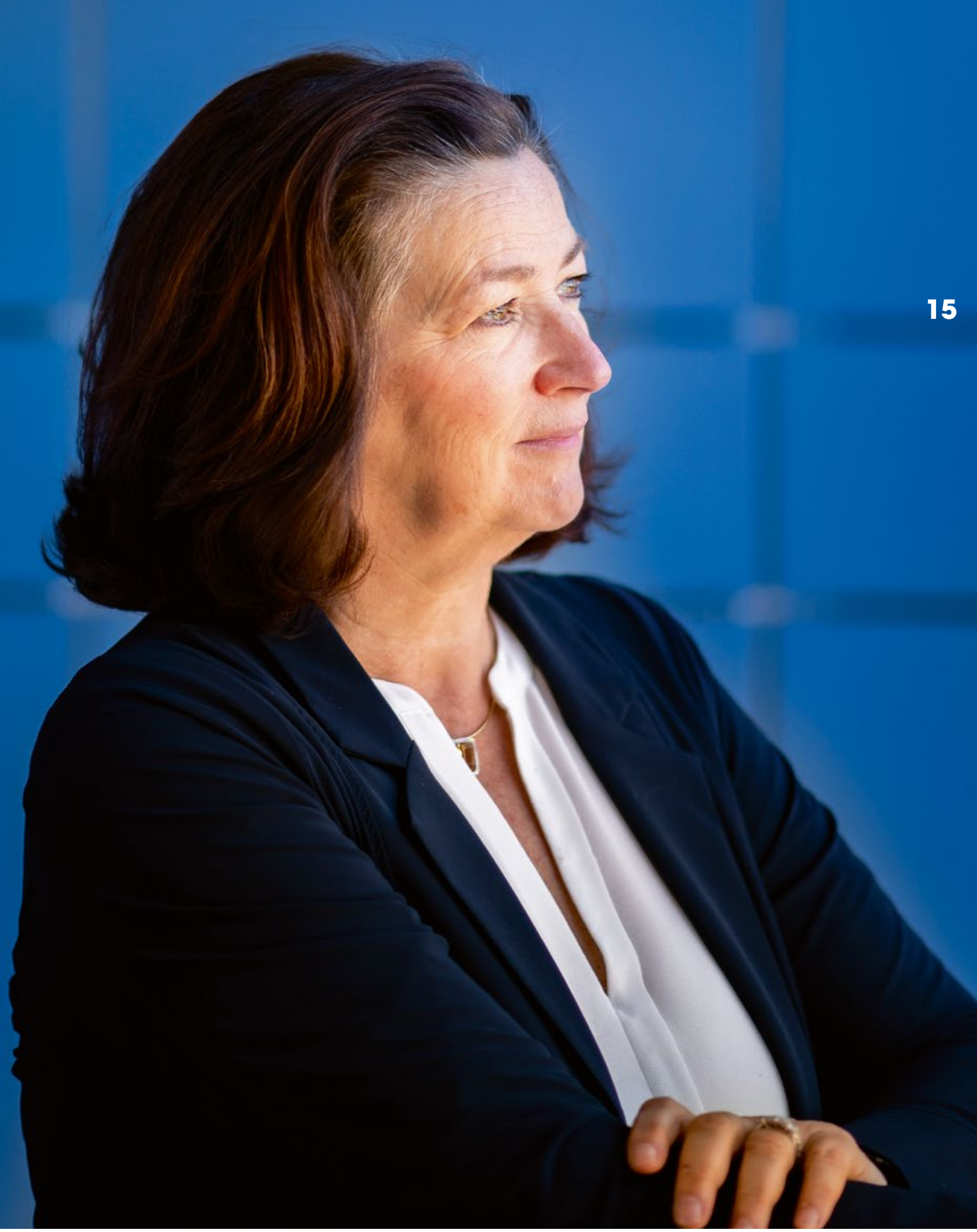

We hebben acute crisisopnames vanuit huis van mensen met dementie, dwaalgedrag of hun partner wordt opgenomen op cohortafdelingen. Verpleeghuizen lopen nu de tweede marathon.'

\section{WAS ER IN VERPLEEGHUIZEN ONNODIG HOGE STERFTE DOOR} TEKORT AAN BESCHERMEND MATERIAAL? 'Nee, er zijn voldoende materialen geweest om volgens de RIVM-richtlijnen te werken. Die schrijven voor dat zorgverleners alleen in bepaalde situaties de middelen mogen gebruiken. De voorraden beschermingsmiddelen waren erg krap. Maar een andere vraag is of zorgverleners in verpleeghuizen zich wel voldoende beschermd voelen. Zij horen via de media en Facebook wilde verhalen over masker- tjes. Ze zien buren met een mondkapje rondlopen. Je kunt de angst weghalen door de experts de richtlijnen te laten uitleggen. Maar dat deed het RIVM niet goed. Het was de eerste keer in de crisis dat ik oprecht boos was. De ergernis daarover stapelde zich op en op 22 april heeft ActiZ een persbericht verstuurd over het tekort aan beschermingsmiddelen. Nog dezelfde dag hadden we overleg met de twee ministers.'

WAAROVER WAS U PRECIES BOOS? 'De vvt had steeds onvoldoende aandacht bij het RIVM. De prioriteit ging naar de acute zorg. Het leek wel "Wie is de Mol?". Heel Nederland keek in spanning of het wel goed zou komen met de beademingsapparatuur en 
de capaciteit aan ic-bedden. Ik heb zelf lang in ziekenhuizen gewerkt. Ik heb veel compassie met ziekenhuizen dat ze nu op adem moeten komen. Maar als Ernst Kuipers roept: "We moeten de productie in ziekenhuizen weer opvoeren", denk ik: "Wacht even, we liggen nog vol van de vorige piek”. De ministers, het RIVM en de GGD'en moeten beseffen dat wij in de verpleeghuizen de tweede marathon lopen.'

\section{HEEFT U VERTROUWEN IN DE PLANNEN VOOR FINANCIËLE} COMPENSATIE? 'In de eerste fase van de crisis hadden verzekeraars, NZa en VWS de boodschap: "Doe wat nodig is. Wij gaan $\mathrm{u}$ helpen. Maakt $\mathrm{u}$ zich geen zorgen over de financiën." Dat was erg goed. In de tweede fase ontstond onduidelijkheid over hoe dat dan moest gebeuren. In de huidige fase zie je oude reflexen bij verzekeraars terugkeren. Normaal onderhandelen we als sector eerst alles uit. Maar deze crisis zijn we samen ingestort. We moesten noodgedwongen de regels aan de kant zetten. Daarom moeten we dit jaar snel en fatsoenlijk afboeken. Laten we de financiële afhandeling 2020 in één keer afboeken. We kunnen hierover geen jarenlange financiële onzekerheid hebben.'

\section{Na de crisis}

Hete hangijzers van voor de coronacrisis zijn even in de ijskast geplaatst. Iedereen begrijpt dat verpleeghuizen en aanbieders van wijkverpleging momenteel wel wat anders aan hun hoofd hebben dan plannen voor een nieuwe bekostiging. Wat wel voor de hand ligt, is dat de komende jaren in het teken van bezuinigingen zullen staan. Helder: 'Ik maak me veel meer kopzorgen om het tekort aan personeel. Als we over vijf jaar nog met vakantie willen, zullen we het werk anders moeten organiseren. We zullen met minder mensen meer moeten doen, terwijl we toch warme zorg blijven leveren.'

HOE ZOU DAT KUNNEN? 'Bij tanteLouise bouwen we de onrust-medicatie af van mensen met dementie. Dat doen we door ze zes weken te observeren waar hun onrust vandaan komt. Als ze beweegdrang hebben, laten we ze gewoon naar buiten, ook al regent het. Er is niets zo frustrerend als een deur die op slot zit. We zetten natuurlijk niet zomaar de deuren open, maar houden de bewoners in de gaten via domotica en gps-tracking. We hebben bijvoorbeeld een mevrouw die twintig keer per dag een boodschap wil doen in het winkeltje van het verpleeghuis. Met active ageing activeren we mensen met dementie. We doen fysieke en mentale activiteiten. Dat maakt ze weer zelfstandiger en het remt het proces van dementeren af. Als cliënten overdag actiever zijn, slapen ze beter en heb je 's nachts minder nachtzorg nodig. Verder gebruiken we technische innovaties om werkprocessen aan te passen, zoals slimme looproutes en slim incontinentiemateriaal.'

'Ik hoop dat mensen door de coronacrisis beseffen hoe belangrijk de ouderenzorg is. Maar ook als we ons maximaal inzetten, zal er een tekort zijn aan zorgverleners. Daarom zullen we de adviezen van de commissie-Bos ter harte moeten nemen: digitalisering, bouwen en samenwerken.'

IS HET BOUWEN NU NIET TE VRIJBLIJVENDHEID? 'Er ligt een maatschappelijke opgave voor woningcorporaties en gemeenten om samen met ons te zorgen voor voldoende verpleeghuiscapaciteit en geschikte geclusterde seniorenwoningen. Met een breder aanbod van geclusterde ouderenwoningen, kunnen ouderen langer zelfstandig wonen en meer voor elkaar zorgen. Ouderen in de wijk leunen ook vaak op de faciliteiten van verpleeghuizen. Denk aan het restaurant, het Alzheimer-café en voorzieningen voor dagbesteding.'

\section{WAT ZIJN GEVOLGEN VAN DE CORONACRISIS DIE U GRAAG WILT BEHOUDEN? 'Het digitale werken heeft een enorme vlucht genomen. Bij tanteLouise hebben we een digitale bril waarmee zorgverleners op afstand meekijken. De reserves die daartegen be- stonden, zijn weggenomen nu behandelaren mer- ken dat het wel erg handig is als ze op afstand kunnen meekijken. Ook is de drempel voor digi- taal overleg een stuk lager. Ik hoop dat we aan dergelijke vernieuwingen wennen. Ik verwacht wel dat wanneer er eenmaal een vaccin is, mensen geneigd zijn terug te vallen in oude gewoontes.'}

\section{HET OPZIJ SCHUIVEN VAN DE REGELS EN HET ONDERLINGE VERTROUWEN IS DOOR VEEL ZORGAANBIEDERS ALS EEN VERADEMING ERVAREN. KAN DAT NIET BLIJVEN? 'Het is} onvermijdelijk dat controlemechanismen en regeltjes weer deels terugkomen. Nu hebben we elkaar nodig om problemen op te lossen. Ik doe dat liever dan politiek bedrijven. Ik hoop dat ons geheugen zo fris blijft dat we ons het vertrouwen en de openheid van nu kunnen herinneren. Als we echt gaan voor samenwerking, winnen we aan snelheid en effectiviteit.' 


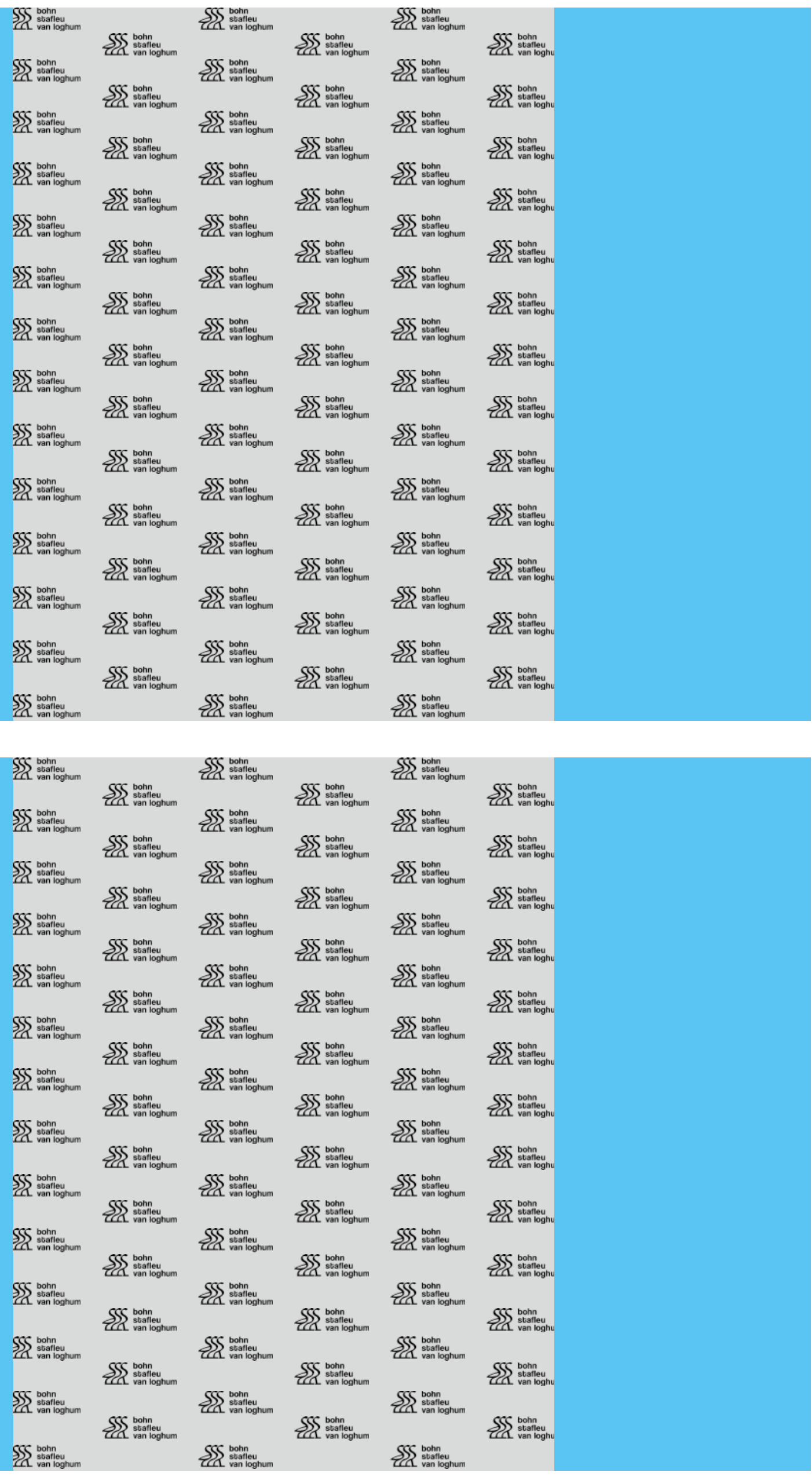




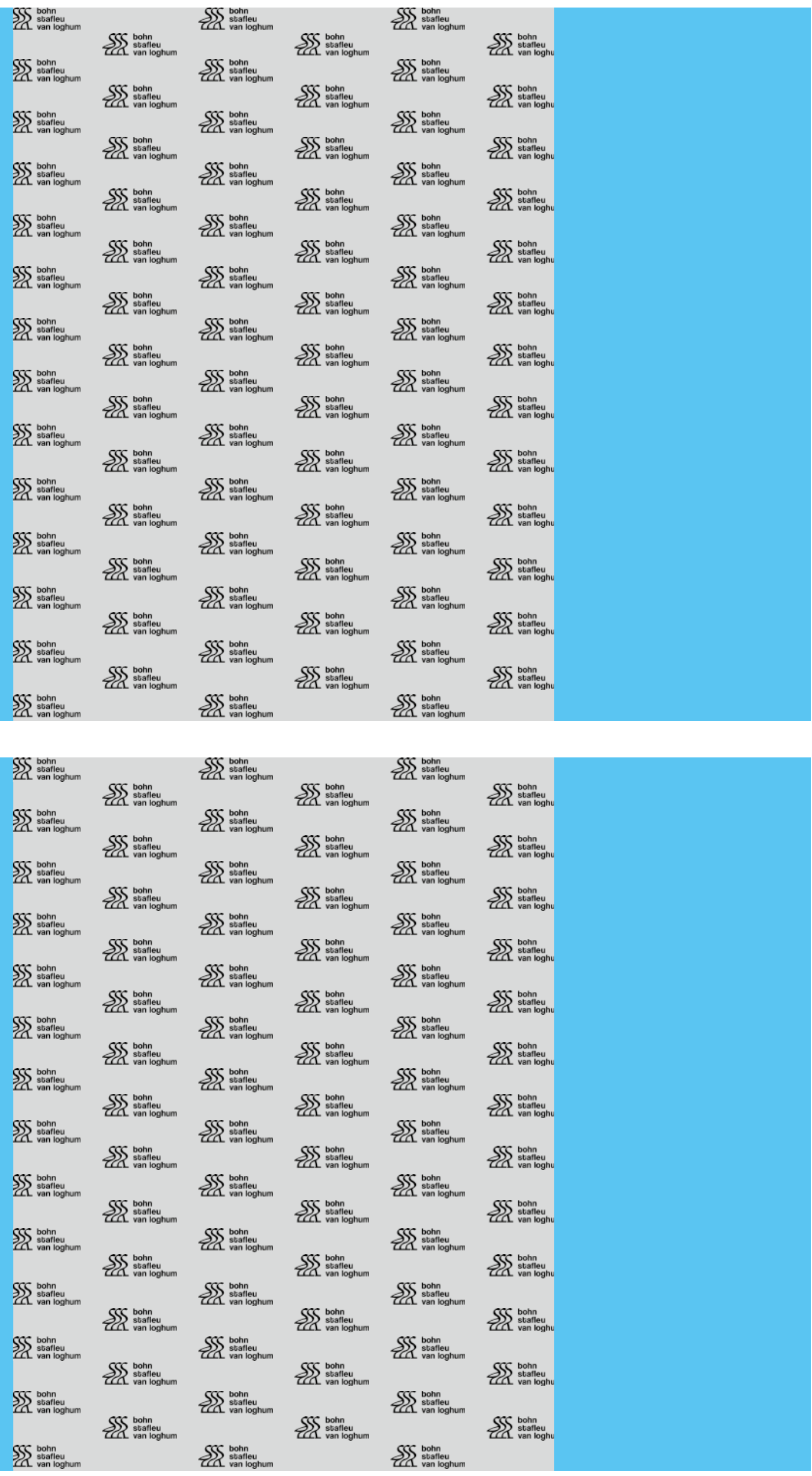

